\title{
THE RELATIONS BETWEEN SAFETY CULTURE AND QUALITY CULTURE
}

doi: $\quad 10.2478 /$ czoto-2019-0002

Date of submission of the article to the Editor: 05/11/2018

Date of acceptance of the article by the Editor: 10/12/2018

Radosław Wolniak ${ }^{1}$ - orcid id: 0000-0003-0317-9811

Marcin Olkiewicz ${ }^{2}$ - orcid id: 0000-0001-6181-6829

${ }^{1}$ Silesian University of Technology, Organization and Management Faculty, Economics and Informatics Department, Poland, radek_wol@o2.pl

${ }^{2}$ Koszalin Technical University, Economic Faculty, Management Department, Poland

Abstract: The publication focuses on issues related to the culture of safety and the culture of quality. The aim of the publication is to analyze the literature on the subject of these two concepts and to present the relationship between the culture of quality and culture of safety. The integrated system should include the culture of an integrated management system, which will include issues related to individual partial cultures, for example the cultures of quality and safety presented in this publication. This concept includes all elements of the culture of quality and culture of occupational safety. This opens up new, interesting research fields, consistent with contemporary trends in both theory and practice of management sciences. Considering the practical dimension of management sciences, it is difficult to consider separately the "culture" of individual subsystems, where in most enterprises, especially industrial ones, these systems do not appear separately and are implemented in the form of an integrated system.

Keywords: safety culture, quality culture, organizational culture, integrated management systems, quality management

\section{INTRODUCTION}

The notion of organizational culture has long been present in the management science literature. There are numerous definitions of this approach and numerous methods of its study. The concept of organizational culture has evolved from concepts related to the study of culture characteristic in particular areas of management science.

This publication addresses two areas: the culture of security and the culture of quality. The aim of the publication is to analyze the literature on the subject of these two concepts and to present the model of relationship between the culture of quality and culture of safety. 


\section{THEORETICAL BACKGROUND}

Organizational culture has a very significant impact on quality management. The way of acting, thinking, and behavior of residents in particular countries very often significantly determines the possibilities of implementing TQM and other pro-quality management concepts in a given country (Wolniak, 2017). The social sphere is one of the factors that have the greatest impact on the efficiency and effectiveness of each organization (Hawrysz and Hys, 2011). If in a country, organizational culture is not conducive to quality management (aversion to a team approach, large distance to power, etc.), it is very difficult to change it, because it takes a long time to do it properly (Wolniak, 2012). The quality culture can be presented as a subset of the organizational culture, in this case particularly focused on quality (Figure 1).

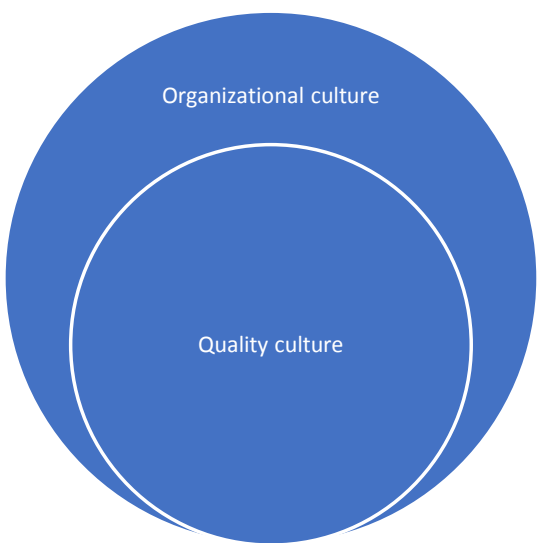

Fig. 1. Organizational culture and quality culture

The issue of pro-quality culture is included in many strategies of the contemporary functioning organization. For example, the Toyota company's rules called "Toyota's way" draw attention to the issues related to building an appropriate organizational culture, enabling the achievement of high quality (Molenda, 2012; Ehlers, 2009, Cronemyr et al., 2017; Adebanjo and Kehoe, 1998). In these rules, it is stated that a culture must be built to do everything right the first time. (Haffer, 2015) Such a proquality organizational culture will enable employees' involvement and implementation of other principles of "Toyota's way". Similarly, in many other organizations, proquality issues are an important component of organizational culture (Sułkowski, 2013; Zayda and Rostron, 2018; Quartey, 2017; Bahn, 2012).

Based on the results of empirical research $\mathrm{R}$. Wolniak proposed a typology of organizational culture that takes into account pro-quality culture (Wolniak, 2012):

- pro-quality culture (culture of success) - is characterized by a positive attitude to uncertainty and an attitude towards achieving status,

- avoidance culture - occurs when achieving status is accompanied by a negative attitude to uncertainty,

- forced change culture - a culture in which a positive relationship to uncertainty is accompanied by the attribution of status,

- conservative culture (rigid culture) - there is a negative attitude to uncertainty and at the same time attributing status approach.

According to the presented typology in the pro-quality culture, which can also be called the culture of success, there is an attitude towards achieving both personal and organization successes. In such a culture, emerging changes and new circumstances 
on the market are treated as an opportunity that should be used by the organization to improve its competitive position. The ability to achieve a higher position in the organization, thanks to good work, commitment and achieving good results, triggers creativity and ingenuity in employees. In this way, the company becomes flexible, prone to change, innovative and continuously improving all products and processes. It has an attitude towards the customer and meeting his needs. Enterprises define their goals in a measurable way, while rewards and promotion of employees depends on their fulfillment. Employees are only billed for fulfilling the organization's goals, while other factors such as formal diplomas, age, gender, etc. are not taken into account when assessing their achievements. In today's turbulent environment, it is a model culture that Polish companies should aspire to.

As in the case of organizational culture or quality culture, in the literature of the subject we can encounter numerous definitions of the security culture (Lejko, 2010; Lis, 2013; Skurjat 2014; Sujova and Cierna, 2013; Wyrwicka, 2014; Żurakowski, 2015; Łuczak, and Wolniak, 2016). One can distinguish definitions related to safety culture in security sciences and approaches closer to management sciences that understand security culture, as a culture related to occupational health and safety (GembalskaKwiecień, 2012; Gembalska-Kwiecień 2017; Gembalska-Kwiecień, 2018; Pacana and Stadnicka, 2017; Pacana, 2014).

The term safety culture was first used in a document developed as a result of the Chernobyl disaster - it identifies a set of human traits and attitudes that relate to the culture of security (Mitroussi, 2003; Phusavat, 2017; Roberts, et al., 2012, Clarke, 2003).

The culture of security in the first of these trends can be defined as the total material and non-material property of a man who serves his broadly understood defense. It serves to maintain (cultivate), recover (when lost) and increase the level of security of a given entity. It consists of three dimensions: mental-spiritual, organizational-legal and material (Piwowarski, 2012).

Another definition included in this trend is the definition according to which the culture of security and defense is a kind of social matrix. It is a model of basic assumptions, values, norms, rules, symbols and beliefs influencing the perception of challenges, opportunities and threats, as well as the way of perceiving security and thinking about it and the related behavior and actions (interaction) of entities in different way through these entities learned and articulated in the processes of broadly understood education, including in the natural processes of internal integration and external adaptation and other organizational processes, and in the process of strengthening broadly (not only militarily) understood defense, serving the harmonious development of these entities and achieving by them the broadest understood security for the benefit of themselves, but also for the environment (Cieślarczyk, 2010).

The security culture in the second of these trends can be defined as a set of features and attitudes of organizations and people that make safety matters the top priority. According to the definition, the security culture refers to both the attitudes or attitudes of employees as well as to the structure of a given organization. It deals with issues related to the fulfillment of all safety requirements (Manning, 2018; Arezes, 2003; Chinda, 2008).

Another definition is the definition presented by the British Health and Safety Commission (HCS). According to it, safety culture is a product of individual and group values, attitudes, perceptions, competences and behavior patterns that determine the 
commitment and style of managing the organization's safety and health (IAEA, 1991; Pagieła, 2016). Relations between organizational culture and security culture are presented in Figure 2. From this point of view, security culture can be seen as a subset of organizational culture.

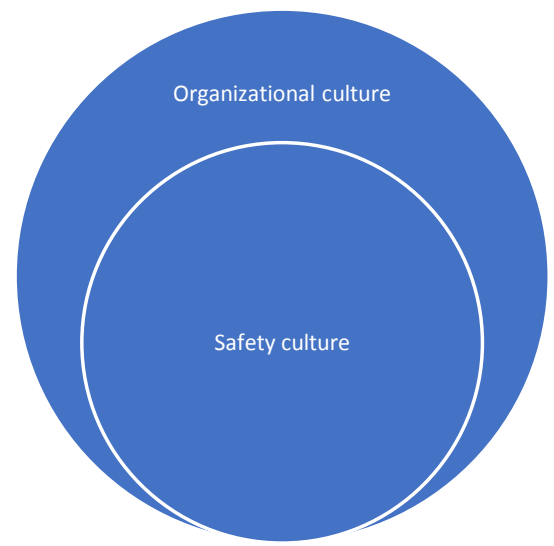

Fig. 2. Organizational culture and safety culture

The following components of the safety culture are distinguished in the literature (Studenski, 2000):

- the attitude towards health and safety regulations,

- trust in the preventive role of OSH regulations,

- the attitude of superiors towards subordinates taking risk,

- the attitude of employees who take risks at work,

- the attitude of supervisors to employees who require compliance with safety standards,

- the attitude towards OHS training,

- the prestige of the services and the rank of the workplace,

- employers' involvement in the organization of safe working conditions.

\section{RESULTS AND DISCUSION}

Table 1 presents the relationships between the characteristics of the quality culture and safety culture. As the analysis shows, both concepts are similar to each other in terms of activities and recommendations. Only in the case of a safety culture, the emphasis is put on health and safety at work issues, while in the case of a quality culture, the emphasis is placed on the quality and quality management in the organization.

The relationship between quality and safety was noticed by Piwowarski, stating that the management of processes becomes a separate value with qualitative improvement connecting with the subject of security with an attitude that builds high motivation for him to work, enabling him to derive satisfaction and happiness as selfrealization (Piwowarski, 2014).

As has been shown in Figures 1 and 2, the quality culture and safety culture are subsets of the broadly understood organizational culture. Considering the problem from the point of view of the system approach, organizations rarely implement "clean" quality management systems or occupational health and safety management systems. In practice, these systems take the form of an integrated system consisting 
of several subsystems, including the quality management subsystem and the occupational health and safety management subsystem. This type of approach is currently most commonly used in the implementation of a system approach in line with the requirements of the relevant ISO standards (Czajkowska et al., 2018; Kafel, 2017; Pacana and Stadnicka, 2017).

Table 1.

Features of the quality culture and safety culture

\begin{tabular}{|l|l|}
\hline \multicolumn{1}{|c|}{ Quality culture } & \multicolumn{1}{|c|}{ Safety culture } \\
\hline $\begin{array}{l}\text { employees' awareness of the importance of } \\
\text { quality problems }\end{array}$ & $\begin{array}{l}\text { employee awareness (awareness of the } \\
\text { importance of safety-related problems) }\end{array}$ \\
\hline $\begin{array}{l}\text { knowledge and competence regarding } \\
\text { quality (acquired by training and instructing } \\
\text { personnel and through its independent } \\
\text { learning) }\end{array}$ & $\begin{array}{l}\text { knowledge and competences regarding } \\
\text { safety }\end{array}$ \\
\hline $\begin{array}{l}\text { commitment of management and employees } \\
\text { to all kinds of activities aimed at improving } \\
\text { and maintaining quality within all activities in } \\
\text { the organization }\end{array}$ & $\begin{array}{l}\text { involvement at managerial level requires } \\
\text { emphasizing on the priority of security, and } \\
\text { on the common goals between managers } \\
\text { and employees }\end{array}$ \\
\hline $\begin{array}{l}\text { monitoring, controlling and auditing the } \\
\text { quality level in the organization, undertaking } \\
\text { corrective and preventive actions }\end{array}$ & $\begin{array}{l}\text { supervising (control and review) with the } \\
\text { readiness to respond to the inquisitive } \\
\text { attitudes of employees }\end{array}$ \\
\hline $\begin{array}{l}\text { motivation to maintain a culture of quality - } \\
\text { setting tasks and bonus and punishment } \\
\text { systems }\end{array}$ & $\begin{array}{l}\text { motivation to maintain a culture of safety - } \\
\text { setting tasks and bonus and punishment } \\
\text { systems }\end{array}$ \\
\hline $\begin{array}{l}\text { responsibility for quality activities (through } \\
\text { formal assignments and descriptions of } \\
\text { duties and their understanding by } \\
\text { employees) }\end{array}$ & $\begin{array}{l}\text { responsibility for safety activities (through } \\
\text { formal assignments and job descriptions and } \\
\text { their understanding by employees) }\end{array}$ \\
\hline
\end{tabular}

Source: Own work on basis: (Gembalska-Kwiecień, 2012; Gembalska-Kwiecień, 2017; Gembalska-Kwiecień, 2018; Haffer, 2005; Skurjat, 2014; Studenski, 2000; Sujowa and Cierna, 2013; Sułkowski, 2013; Wolniak, 2012)

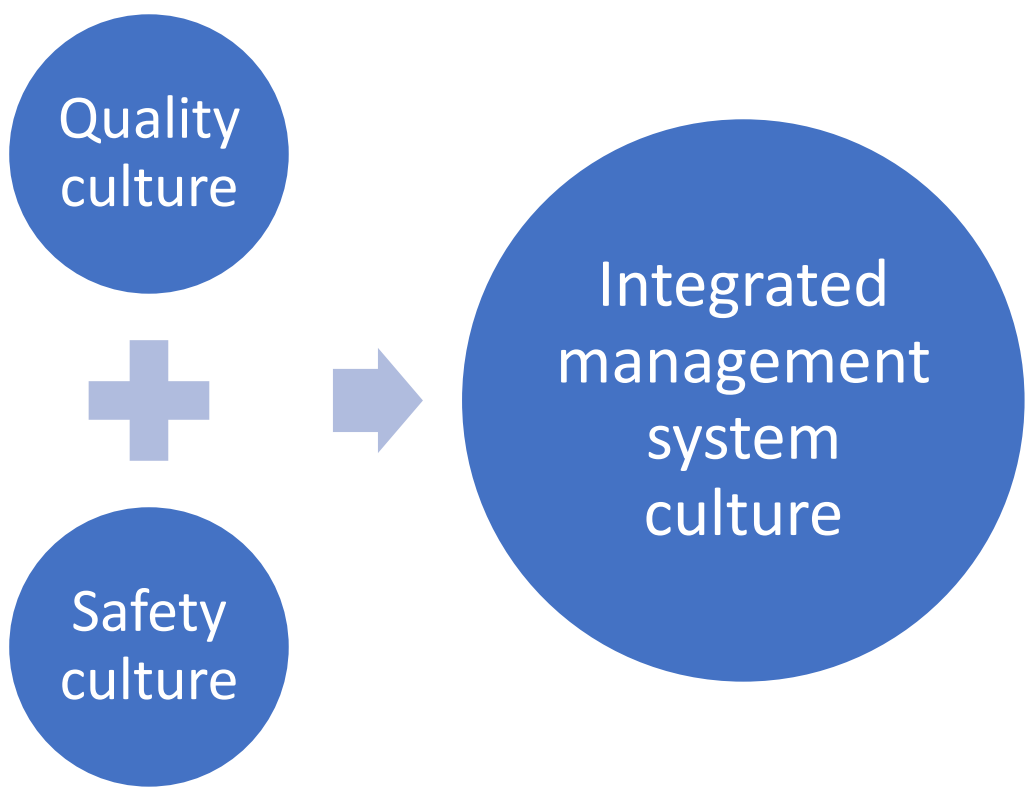

Fig. 3. Integrated management system culture 
Considering cultural considerations, in this case we can assume that the integrated management system should include the culture of an integrated management system, which will contain issues related to individual subsystems cultures, for example the quality cultures and safety culture considered in this publication (Figure 3). It's not difficult because, as shown in Table 2, these concepts are similar, based on similar assumptions and require similar actions.

\section{CONCLUSION}

The problems presented in the publication were focused on the concepts of a quality culture and safety culture. Taking into account existing approaches both to the quality culture and safety culture as well as the fact that there is currently the rise in the implementation of integrated management systems process, which is composed of, among others: quality management system and occupational safety and health management system, the concept of integrated management system culture was proposed. This concept includes all elements of the quality culture and occupational safety and health culture. This opens up new, interesting research fields, consistent with contemporary trends in both theory and practice of management sciences. Considering the practical dimension of management sciences, it is difficult to consider separately the "culture" of individual subsystems, where in most enterprises, especially industrial ones, these systems do not appear separately and are implemented in the form of an integrated system.

\section{ACKNOWLEDGMENT}

The paper was prepared and financed from the BK-231/ROZ1/2018 project.

\section{REFERENCES}

Adebanjo, D., Kehoe D. 1998. An evaluation of quality culture problems in UK companies. International Journal of Quality Science, 3, 275-286, https://doi.org/10.1108/13598539810370486.

Arezes, P.M. 2003. The role of safety culture in safety performance measurement. Measuring Business Excellence, 4, 20-28, https://doi.org/10.1108/ 13683040310509287.

Bahn, S. 2012. Moving from contractor to owner operator: impact on safety culture $-a$ case study. Employee Relations, 2, 157-172, https://doi.org/10.1108/ 01425451311287853.

Chinda, T. 2008. Structural equation model of construction safety culture, Engineering. Construction and Architectural Management, 2, 114-131, https://doi.org/10.1108/09699980810852655.

Cieślarczyk, M. 2010. Kultura bezpieczeństwa i obronności. Wydawnictwo Akademii Podlaskiej, Siedlce, Poland.

Clarke, S. 2003. The contemporary workforce: Implications for organizational safety culture. Personnel Review, 1, 40-57, https://doi.org/10.1108/00483480310454718.

Cronemyr P., Bäckström, I., Rönnbäck A. 2017. Quality culture deployment - using behaviours to explain, diagnose and improve a quality culture. International Journal of Quality and Service Sciences, 3/4, 498-518, https://doi.org/10.1108/IJQSS-022017-0008. 
Czajkowska, A., Ingaldi, M., Pacana, A. 2018. Projektowania $i$ wdrażanie zintegrowanych systemów zarządzania. Wydawnictwo Politechniki Rzeszowskiej, Rzeszów, Poland.

Ehlers, U.D. 2009. Understanding quality culture, Quality Assurance in Education. 4, 343-363, https://doi.org/10.1108/09684880910992322.

Gembalska-Kwiecień, A. 2012. Kształtowanie kultury bezpieczeństwa w przedsiębiorstwie. Zeszyty Naukowe Politechniki Śląskiej. Seria Organizacja i Zarządzanie, 63, 189-198.

Gembalska-Kwiecień, A. 2017. Czynnik ludzki w zarządzaniu bezpieczeństwem pracy w przedsiębiorstwie. Wybrane zagadnienia, Wydawnictwo Politechniki Śląskiej, Gliwice, Poland.

Gembalska-Kwiecień, A. 2018. Zarys problematyki kultury bezpieczeństwa pracy na przykładzie wybranego przedsiębiorstwa. Promotor BHP, 5, 22-27.

Gębalska-Kwiecień, A. 2017. Fundamentals of an effective corporate safety culture. Ekonomia i Prawo, 4, 401-411.

Haffer, R. 2005. Kultura jakości i sposoby jej kształtowania. Problemy Jakości, 11, 58.

Haffer, R. 2005. Kultura jakości jako warunek międzynarodowej konkurencyjności polskich przedsiębiorstw. Problemy Jakości, 12, 6-8.

Hawrysz, L., Hys, K. 2011. Kultura jakości w organizacjach sektora publicznego. Ekonomika i Organizacja Przedsiębiorstwa, 10, 52-58.

IAEA. 1991. Kultura bezpieczeństwa, Międzynarodowa Agencja Energii Atomowej w Wiedniu. Safety Series, 75 INSAG-4.

Jacques, E. 1951. The Changing Culture of a Factory. Tavistock, London 1951.

Kafel P.: Integracja systemów zarządzania. Trendy, zastosowania, kierunki doskonalenia. Wydawnictwo Uniwersytetu Ekonomicznego w Krakowie, Kraków, Poland.

Lejko, Z. 2010. Kultura bezpieczeństwa w przedsiębiorstwie. Atest, 8, 36-48.

Lis, K. 2013. Kultura $i$ klimat bezpieczeństwa pracy. Studia Oeconomica Posnaniensia, 7, 7-16.

Łuczak, J., Wolniak, R. 2016. Integration of quality environment and safety management systems in a foundry. Metalurgija, 4, 843-845.

Manning, L. 2018. The value of food safety culture to the hospitality industry. Worldwide Hospitality and Tourism Themes, 3, 284-296, https://doi.org/10.1108/WHATT-02-2018-0008.

Mitroussi, K. 2003. The evolution of the safety culture of IMO: a case of organisational culture change. Disaster Prevention and Management: An International Journal, 1, 16-23, https://doi.org/10.1108/09653560310463810.

Molenda, M. 2012. Znaczenie wartości organizacyjnych w rozwoju kultury jakości. Zeszyty Naukowe Politechniki Śląskiej. Seria Organizacja i Zarządzanie, 63a, 209219.

Pacana, A., Stadnicka, D. 2017. Nowoczesne systemy zarządzania jakością zgodne z ISO 9001:2015. Wydawnictwo Politechniki Rzeszowskiej, Rzeszów, Poland.

Pagieła, J. 2014. Bezpieczeństwo behawioralne jako element kształtujący kulturę bezpieczeństwa. Zeszyty Naukowe Politechniki Śląskiej. Seria Organizacja i Zarządzanie, 73, 471-480. 
Pagieła, J. 2016. Diagnoza kultury bezpieczeństwa w wybranych przedsiębiorstwach krajów UE w świetle badań pilotażowych. Zeszyty Naukowe Politechniki Śląskiej. Seria Organizacja i Zarządzanie, 93, 381-392.

Phusavat, K. 2017. Safety management system in automotive and energy industries. International Journal of Quality \& Reliability Management, 4, 569-580, https://doi.org/10.1108/lJQRM-08-2012-0116.

Piwowarski, J. (2012). Kultura bezpieczeństwa i jej trzy wymiary. [w:] Kultura bezpieczeństwa. Nauka, praktyka, refleksje, ed. W. Hrynicki, J. Piwowarski, Wyższa Szkoła Bezpieczeństwa Publicznego i Indywidualnego, Apeiron, Kraków, Poland.

Piwowarski, J. 2014. Kultura bezpieczeństwa a zarządzanie bezpieczeństwem. Studia i Materiały. Miscellanea Oeconimicae, 3, 87-102.

Quartey, S.H. 2017. Examining employees' safety behaviours: an industry-level investigation from Ghana. Personnel Review, 8, 1915-1930, https://doi.org/10.1108/PR-06-2016-0146.

Roberts, A., Kelsey, J, Smyth, H., Wilson, A. 2012. Health and safety maturity in project business cultures. International Journal of Managing Projects in Business, 4, 776-803, https://doi.org/10.1108/17538371211269059.

Skurjat, K. 2014. Kultura bezpieczeństwa pracy w organizacji. Logistyka, 5, 13681374.

Studenski, R. 2000. Kultura bezpieczeństwa pracy $w$ przedsiębiorstwie. Bezpieczeństwo Pracy, 9, 1-4.

Sujova, E., Cierna, H. 2013. Corporate culture as a tool to improve safety culture. Management Systems in Production Engineering, 3, 49-52.

Sułkowski, A. 2013. Kultura jakości w zarządzaniu, czyli pomiędzy tożsamością a kulturą organizacyjną. Przedsiębiorczość i Zarządzanie, 8, 25-37.

Wadick, P. 2010. Safety culture among subcontractors in the domestic housing construction industry. Structural Survey, 2, 108-120, https://doi.org/10.1108/02630801011044217.

Wolniak, R. 2012. Wymiary kulturowe polskich organizacji a doskonalenie zarządzania jakością. monografia, Wydawnictwo CeDeWu, Warszawa, Poland.

Wolniak, R. 2017. Analiza wskaźników nasycenia certyfikatami ISO 9001, ISO 14001 oraz ISO/TS 16949 oraz zależności pomiędzy nimi. Zeszyty Naukowe Politechniki Śląskiej. Seria Organizacji i Zarządzanie, Gliwice, 108, 421-430.

Wyrwicka, M.K. (2014). Kultura przedsiębiorstwa a odczucie bezpieczeństwa. Zeszyty Naukowe Politechniki Poznańskiej. Organizacja i Zarządzanie, 63, 195-208.

Zayda, J.T., Rostron, I. 2018. The development of a safety and quality culture assessment tool from a longitudinal. mixed-method research journey, Worldwide Hospitality and Tourism Themes, 3, 313-329, https://doi.org/10.1108/WHATT-022018-0006.

Żurakowski, Z. (2015). Kultura bezpieczeństwa w przedsiębiorstwie. Zeszyty Naukowe Politechniki Śląskiej. Seria Organizacja i Zarządzanie, 77, 323-330. 